\title{
Integrating sense of place in planning and management of multifunctional river landscapes: experiences from five European case studies
}

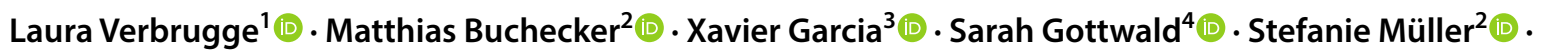 \\ Søren Præstholm ${ }^{5}$ (i) Anton Stahl Olafsson ${ }^{6}$ (i)
}

Received: 15 September 2018 / Accepted: 13 March 2019 / Published online: 23 March 2019

(c) The Author(s) 2019

\begin{abstract}
River landscapes are complex social-ecological systems with many benefits for people. A common challenge is to integrate social values in river planning and management. In particular, there is a paucity of research on the meaning and significance of place in river recreation and how people feel emotionally and spiritually connected to river landscapes. Based on five European case studies, this study compares different methods and approaches for mapping sense of place in river landscapes and subsequently addresses the question of how these studies can inform participatory processes. The case studies are set in diverse geographical, institutional and policy contexts, including the planning and evaluation of river restoration projects in Switzerland, Denmark, Germany and Spain and the monitoring of the effects of newly constructed river dams in the Netherlands. This comparative study is a first step in understanding the breadth of analytical and spatial approaches that can be used to assess sense of place in river landscapes and their implications for resilient river landscape planning and management.
\end{abstract}

Keywords Place attachment $\cdot$ Place meanings $\cdot$ PPGIS $\cdot$ Public participation $\cdot$ River restoration $\cdot$ Social-ecological system

Handled by: Johan P. Enqvist, University of Cape Town Department of Environmental and Geographical Science, South Africa.

Electronic supplementary material The online version of this article (https://doi.org/10.1007/s11625-019-00686-9) contains supplementary material, which is available to authorized users.

Laura Verbrugge

lauraverbrugge1@gmail.com

1 Department of Water Engineering and Management, University of Twente, P.O. Box 217, 7500 AE Enschede, The Netherlands

2 Research Unit Economics and Social Sciences, Swiss Federal Research Institute WSL, 8903 Birmensdorf, Switzerland

3 Institute of Regional and Metropolitan Studies of Barcelona, Autonomous University of Barcelona, Plaça del Coneixement, edifici MRA, 08193 Bellaterra, Cerdanyola del Vallès, Spain

\section{Introduction}

Rivers are important for sustaining people's quality of life not only by providing services such as food, water, transportation and recreation, but also through less tangible assets, such as aesthetic, spiritual or other place based values (Everard and Moggridge 2012; Yeakley et al. 2016). River landscapes in Europe are cultural landscapes evolving from a long history of human-nature interactions. They can act

4 Institute of Environmental Planning, Leibniz University Hannover, Herrenhäuserstr. 2, 30419 Hannover, Germany

5 Department of Geosciences and Natural Resource Management, Forest and Landscape College, University of Copenhagen, Nødebovej 77A, 3480 Fredensborg, Denmark

6 Department of Geosciences and Natural Resource Management, University of Copenhagen, Rolighedsvej 23, 1958 Frederiksberg C, Denmark 
as connectors or dividers of people and places, and their role and appearance change over time due to the reciprocal exercises of power by both humans (e.g. damming, channelization) and natural forces (e.g. floods) (Schönach 2017). As such, they can be considered as "agents of cultural power by which social and subjective identities evolve" (Brunckhorst 2000, p. 31). Climate change, urbanization and increasing competition for different land and water uses represent significant challenges for river and floodplain management (Rojas et al. 2013). The recognition that past, current and future developments are a result of complex societal and natural interactions has led to the conceptualization of rivers as social-ecological systems (e.g. Parsons et al. 2016; Dunham et al. 2018; Sendzimir et al. 2018).

Understanding social-ecological systems requires new approaches and indicators that not only consider the current and future biophysical state but also the continued provision of benefits for people (Walker and Salt 2006; Ives and Kendal 2014). Such insights are needed to develop resiliencebased river management strategies that sustain or enhance the capacity of an ecosystem (including people) to maintain its basic functions and structures at times of disturbances (Walker and Salt 2006). Several authors have argued that the sense of place concept offers a way to study the subjective, cultural and relational dimensions of benefits (or services) that people receive from nature and that they may help to explain people's positions in decision-making processes (Cantrill and Senecah 2001; Hausmann et al. 2016; Masterson et al. 2017a, b; Stedman 2016).

As yet, this new social-ecological systems approach is only to some degree reflected in practice, and rivers and floodplains are often seen primarily as physical resources to be managed, controlled, allocated and conserved (Hillman2009) rather than places of social and cultural values. Despite a trend towards integrated and adaptive approaches in river restoration and management (Pahl-Wostl 2015; Angelopoulos et al. 2017), difficulties often remain with embedding local community perspectives in decision making processes (Fliervoet et al. 2015; Henze et al. 2018). Moreover, legal requirements (e.g. the Water Framework Directive and Flood Risk Management Directive in Europe) are often limited to two dimensions, i.e. biodiversity and flood reduction (Straatsma et al. 2017), thereby excluding other pertinent issues such as social justice and place disruption that are attributed to place change (Burley et al. 2007; Begg 2018).

Chan et al. (2012) outline three main challenges for the integration of social values in ecosystem assessments, including the difficulty to quantify non-material values, the difficulty in linking them to specific system or landscape changes, and the fact that benefits may be associated to any service provided, not just cultural ones. Non-material values, such as sense of place, are, therefore, difficult to incorporate in existing procedural frameworks. It is generally assumed that people 'automatically' benefit from implemented river measures due to enhanced recreational opportunities and more attractive residential areas; however, monitoring measures to ensure that this is in fact the case are seldom implemented (Junker et al. 2007).

Outdoor recreation is tied to places, and hence, there seems to be a need for assessment and monitoring programs that focus on sense of place and are contextually relevant under the newer resilience-based approaches to river management (Parsons et al. 2016). River management is concerned with creating socially desirable conditions, such as flood safe areas, areas of high ecological value or attractive recreational areas. A resilient social-ecological system is not by definition one that is socially desirable, but this requires a normative judgment of what are 'desirable systems states' (Carpenter et al. 2001; Stedman 2016). This leads to the question of which river attributes are important to whom, how they enable or enhance the creation of meanings and attachment and what system states enable or support these values. Developing integrated methods and indicators for measuring sense of place will enable the exchange of values and knowledge between the different actors involved (e.g. citizens and planners) (Masterson et al. 2017b).

The overall aim of this study was to provide insights into the underlying assumptions of and motivations for measuring sense of place in river landscapes and to explore the potential of sense of place research for supporting planning and management of multifunctional river landscapes. Here, we understand river planning and management as a broad term including river restoration, river maintenance and adaptation to flood risk. Based on five European cases, we compare different methods and approaches for mapping sense of place of residents and other users of river landscapes and discuss their benefits and limitations. Two questions will guide the cases' study analyses:

R1: How is sense of place conceptualized and measured in each study?

$\mathrm{R} 2$ : What is the potential of these studies to support participatory planning and management of river landscapes?

\section{Background}

The extensive literature on sense of place stretches many disciplines. Stedman (Stedman 2002, p. 561; based on Tuan 1977) provides a useful definition of the concept that includes the "meanings of and attachment to a setting held by an individual or group". Place meanings are often elicited through qualitative research focusing on 
people's descriptions of places and the importance for their identity and livelihoods (e.g. Kianicka et al. 2006). Some examples of place meanings in a river context are the following:

- For floodplain residents, the river landscape may be seen as their home and may remind them of many individual and collective stories (Junker et al. 2007).

- For recreationists, the river can foremost be a scenic or tranquil landscape (e.g. the river as 'tonic') (Davenport and Anderson 2005).

- For environmentalists, rivers may primarily represent an ecosystem for natural species and an expression of ecological values (Menzel and Buchecker 2013).

- For elderly locals or nearby farmers, it may also be a symbol of the community's achievement to control the river (e.g. with dikes) (Buijs 2009).

This comparative study understands sense of place in the context of such qualitative place meanings, but also in the context of place attachment, i.e. place as an attitude object (Williams 2008). Place attachment (Altman and Low 1992) is often measured using psychometric scales distinguishing between different dimensions such as place identity and place dependence (Williams and Vaske 2003). Place identity refers to a deep symbolic attachment (the place becomes a part of your self-identity) (Proshansky et al. 1983, see also Ingalls and Stedman (2017) for a discussion of self-identity in social-ecological systems), whereas place dependence is a more functional attachment which highlights how the place supports certain activities (e.g. boating, fishing) (e.g. Kyle et al. 2005, Stedman 2003). Such quantitative measures can bring insights into the strength of connections between people and places in river landscapes.

There are several important reasons for river managers in particular to consider people-place bonds. A first reason is related to the consequences of large-scale river adaptation measures for local communities. Quinn et al. (2018) surveyed residents of two towns in France who employed different strategies to cope with flood risk: one village adopted a 'living with the flood' strategy while the other opted for elimination of risk through dike reinforcement ('command and control' strategy). While residents of the first village remained to see the river as a dynamic system and had collective memory of floods, inhabitants of the other village lost not only the view of the river, but also their connection to the river (Quinn et al. 2018). A challenge thus lies in keeping or re-establishing a connection to the river so that local communities can continue to form people-place bonds.

A second point is that considerations of place attachment and place meanings are currently underrepresented in decision-making processes addressing environmental change (Agyeman et al. 2009; Adger et al. 2011). Environmental decisions are embedded in broader social dynamics that link personal appraisals of place with structural processes of conflict, inequality and exclusion (Di Masso et al. 2017). While decisions on flood risk management can have a major impact on local communities, they are not necessarily much involved in policy processes, thereby limiting their opportunities to influence such decisions (Junker et al. 2007). Moreover, people may be less inclined to share their emotional ties to a place in traditional public involvement frameworks, suggesting the need for other approaches (Brandenburg and Carroll 1995).

A third reason lies in the importance of sense of place for understanding people's environmental concerns, proenvironmental behaviour and well-being. Recent research has shown that variables measuring people-place bonds are better at predicting environmental concern than sociodemographic variables (Brehm et al. 2013; Armstrong and Stedman 2018). A study among 212 inhabitants of Reunion Island highlights the need for environmental managers to consider place meanings and place dependence, especially when they wish to improve human quality of life and promote pro-environmental behavior (Junot et al. 2018). A previous qualitative study conducted in the Caldes region in Spain found that those residents who reported a stronger attachment to the stream landscape were more committed to its conservation and rehabilitation (Benages-Albert et al. 2015).

Finally, sense of place research can be a good starting point for communication about complex environmental issues and public engagement initiatives (Nicolosi and Corbett 2018). For example, one of the recommendations from an explorative study among local watershed residents in Wisconsin was to develop different outreach strategies for segments of the population that shared similar place meanings (Simoni and Floress 2015).

While sense of place research has the potential to bridge the current gap between river management and the relationships that people develop with river landscapes, there is still a paucity of research on this topic and a limited understanding of the contribution of such local knowledge and values for planning and decision-making (Hillman 2009; Floress et al. 2015).

\section{Methods}

\section{Case study selection}

We compared five case studies set in different geographical, institutional and policy contexts, including the planning and evaluation of river restoration projects 
Fig. 1 Location and main characteristics of the case study areas

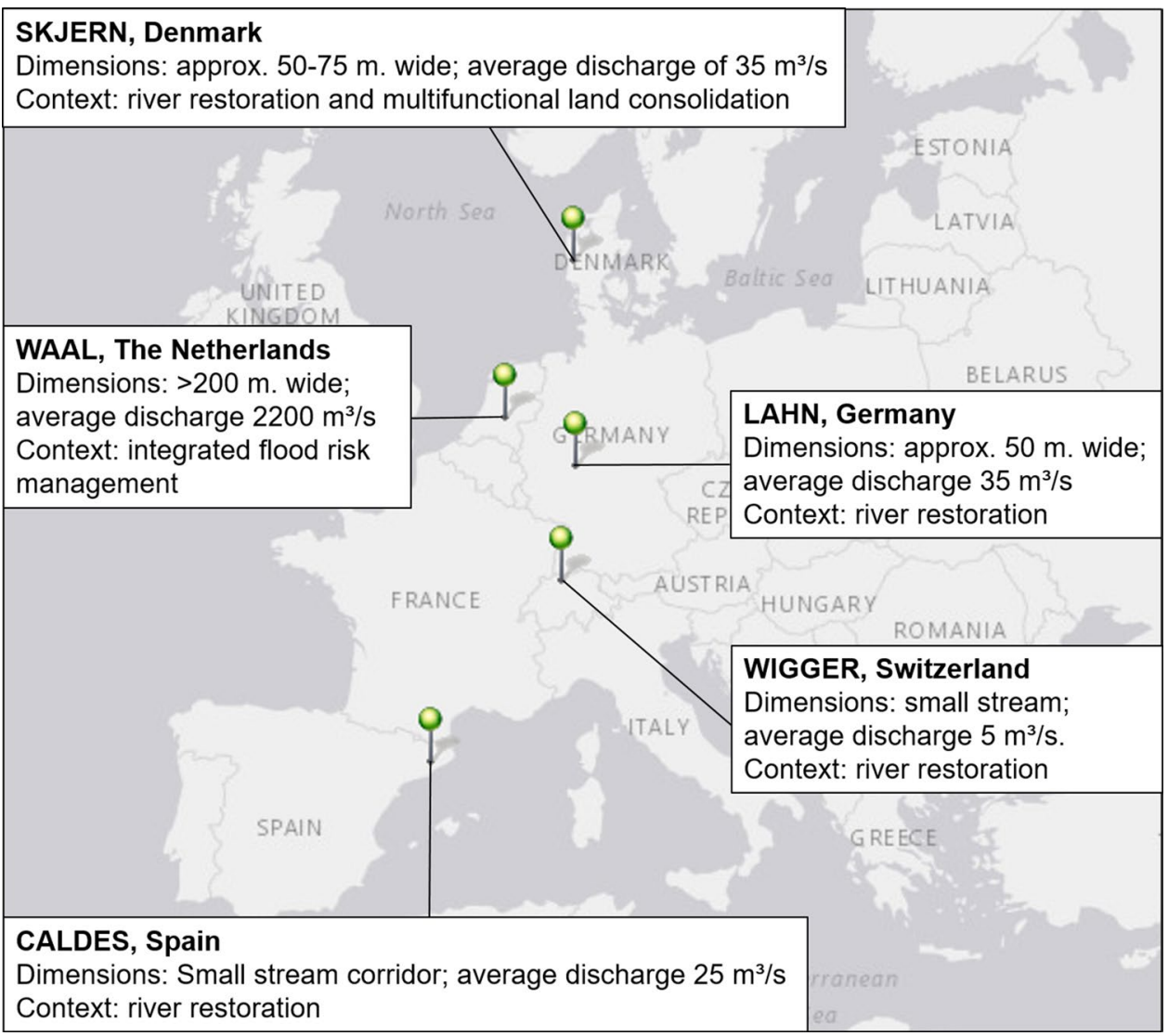

Dimensions: approx. 50-75 m. wide; average discharge of $35 \mathrm{~m}^{3} / \mathrm{s}$ Context: river restoration and multifunctional land consolidation in Switzerland, Denmark, Germany and Spain and the monitoring of the effects of newly constructed river dams in the Netherlands (Fig. 1). The overall criterion for selection of the case studies was that in each case researchers had collected and analysed (spatial) data on sense of place in river floodplains in Europe. In addition, all case studies are embedded in a multi-actor setting involving governments, researchers and societal stakeholders and have the intent to use the information for planning or management purposes. In such transdisciplinary research environments, a contextual inquiry using case studies is a preferred approach in order to capture answers to questions as to how something did (or did not) work out (Yin 1994). All studies were carried out in mixed rural/urban areas and encompassed an $8-140 \mathrm{~km}$ stretch of the river. Among the five cases, there is sufficient diversity in scope, management phase and stakeholder interaction to ensure that many lessons can be learned by (future) river managers. Each case study is represented by at least one co-author who was involved in the study design and data collection, ensuring that we can document the necessary information, as well as additional insights and experiences in navigating the science-policy interface. In addition, available reports and other publications were used as data sources.

\section{Framework for assessing rivers as social-ecological systems}

The choice for using certain concepts and indicators in assessments are not always consciously made, or may be understood differently by researchers and stakeholders involved. Moreover, social valuation methods can be employed in different ways as to serve different purposes, for example to quantify existing services or to elicit new stakeholder perspectives or stories (Tadaki et al. 2017). Parsons et al. (2016) developed a framework for the inclusion of social and ecological aspects of river ecosystems in river management, using principles from resilience thinking and adaptive management. This framework consists of three tiers, focusing on motivations and drivers (why), specific attributes (what), and models, metrics, tools and procedures (how). Here, we apply it to investigate sense of place as an indicator for monitoring river landscapes as social-ecological systems (Fig. 2). In addition to the why, what and how questions, we also report relevant research outcomes and their implications for river management and facilitating participatory processes. Not all case studies will have clearcut results as some are still in progress, but these can report on intended outcomes instead. In the next section, we focus on the findings from the comparison of the five case studies rather than each case individually. These insights are based on 


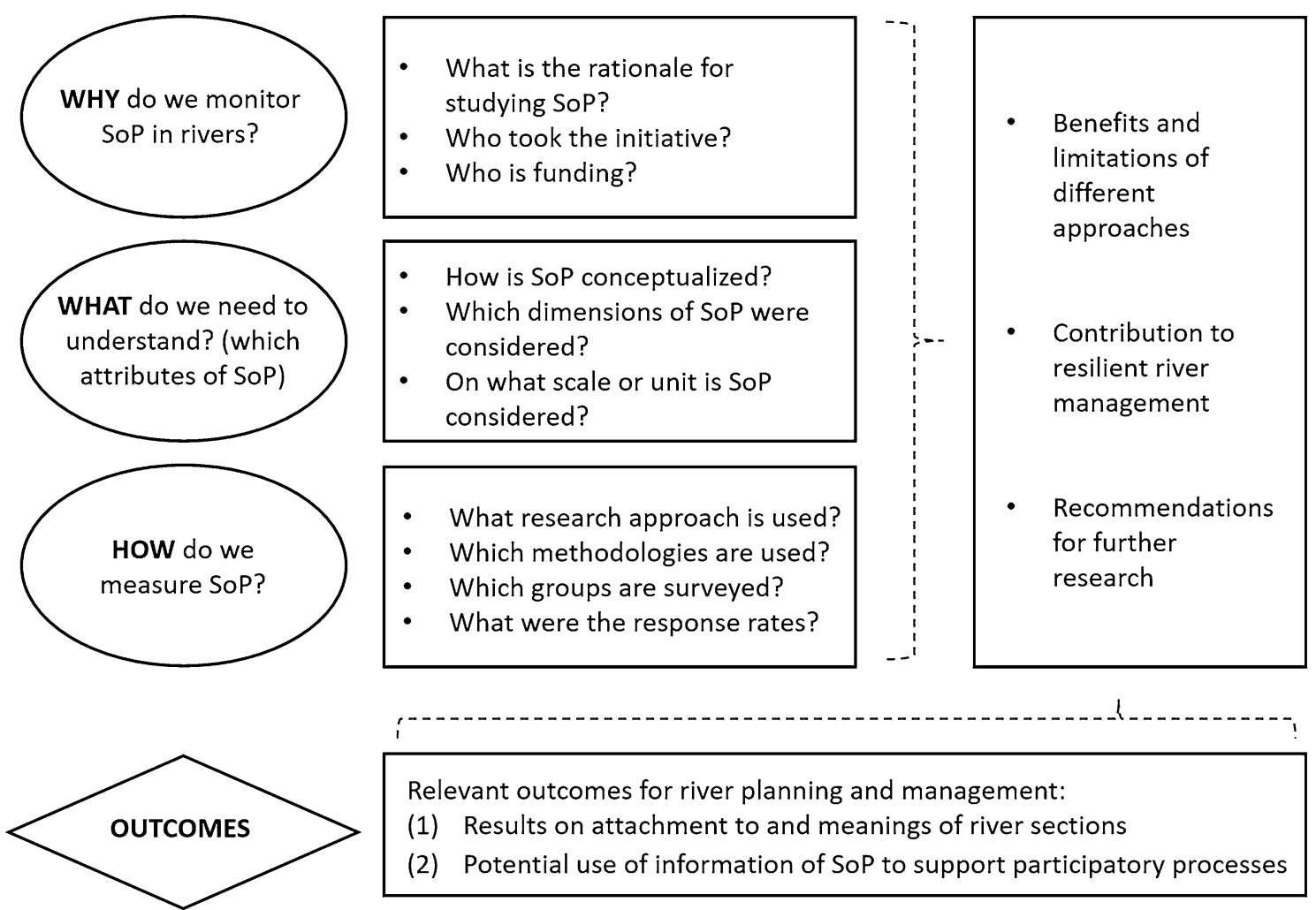

Fig. 2 Framework for evaluating sense of place (SoP) assessments in the five case studies (Adapted from Parsons et al. 2016)

detailed case study descriptions in the Supplementary Material (ESM1 and ESM2). A summarized overview of the main findings is available in Table 1.

\section{Results}

\section{Motivations and drivers for measuring sense of place}

Broadly speaking, all case studies aim to integrate sense of place in an assessment of the impact of human interventions in river landscapes. However, there are some important differences to note. Two case studies highlight the potential of sense of place research to define desirable and locally meaningful characteristics for preservation as well as sites that need improvement (Caldes and Lahn) or sites where landscape values may be in conflict (Caldes). The three other studies are mainly interested in potential changes in sense of place because of (planned) interventions in the river landscape, either because of flood risk measures (Waal), river restoration (Wigger) or a combination of land consolidation and restoration (Skjern). The latter three studies are designed as longitudinal studies with at least two moments of data collection (before and after). Four of the five projects used spatially explicit methods to elicit information on people's preferences and values, i.e. public participation GIS (PPGIS) (e.g. Brown and Reed 2009). All projects were initiated by a governmental organization or a partnership of stakeholders (including a governmental organization), with the exception of the Caldes study where researchers took the initiative. The projects were funded either by a governmental organization, national or European research funding or a combination thereof.

\section{Conceptualization and operationalization of sense of place}

In the case studies, sense of place was either seen as part of a set of landscape values or framed in a recreational context. These different points of departures in the investigation greatly influenced study outcomes, as can be seen from a comparison of the Skjern and Lahn cases. In the Danish Skjern study, researchers asked people to map places for outdoor recreation and then measured attachment to these places. In the German Lahn study, people were asked to map meaningful places and were subsequently asked how often they visit this particular place. Hence, for interpretation of the maps it is important to know what exactly is mapped first. In the Wigger and Lahn study, sense of place and recreational use were measured in parallel, i.e. survey participants were asked 


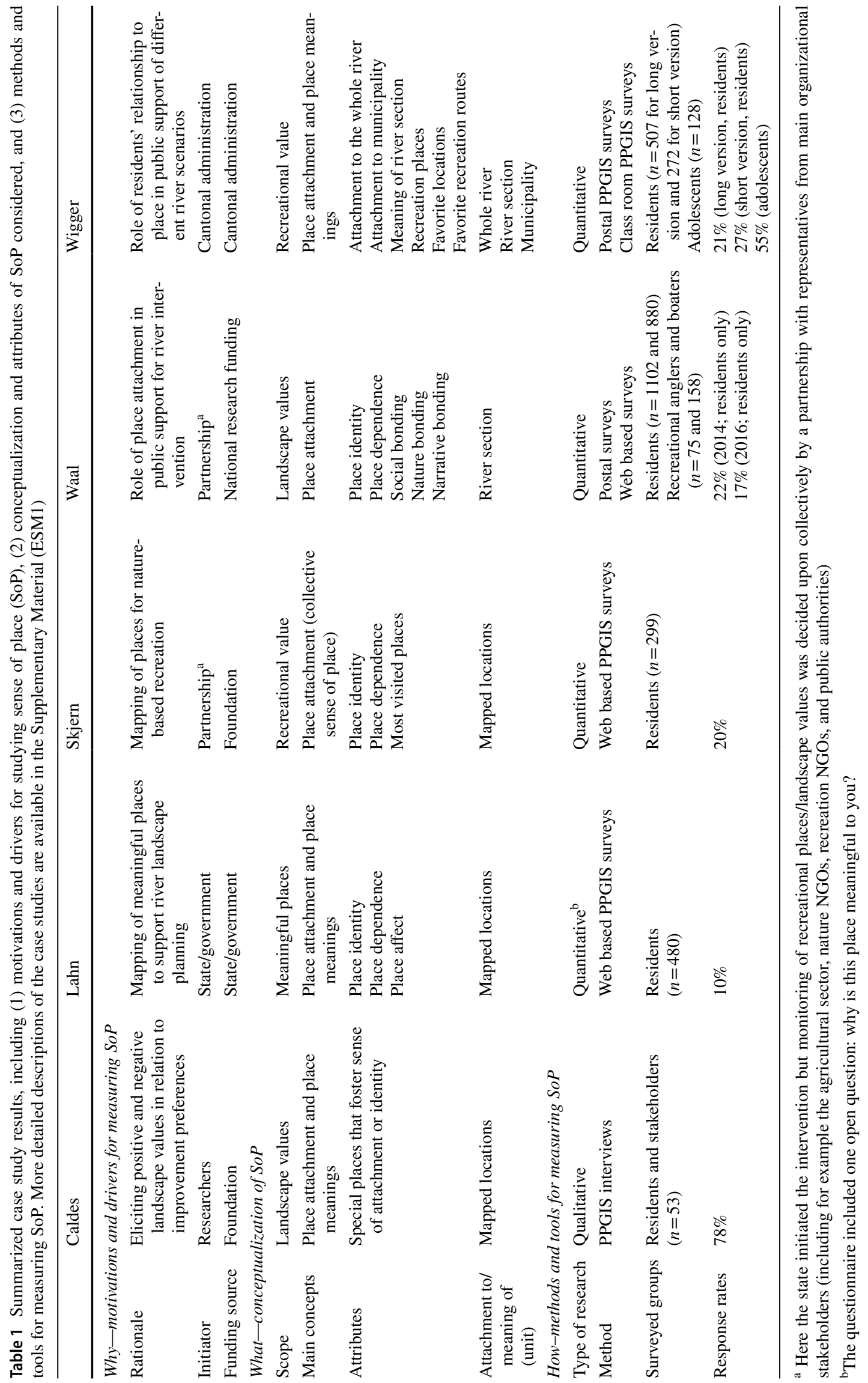


to map places for recreation and their favorite places separately. In addition, the Wigger study asked separate questions regarding people's attachment to the river and the municipality and the different (pre-defined) meanings they associate with the river sections. Yet another approach could be seen in the Waal study, where different user groups were defined beforehand (i.e. recreational anglers, recreational boaters and residents). This created a trade-off between targeting the groups by adapting the sense of place questions to their specific context and jeopardizing the comparability of the survey results between groups. The Caldes study, focusing primarily on special places, revealed that qualitative research provides more tangible results about residents' attachment to specific places, as the respondents can express themselves verbally and this might disclose more insights into the nature of the attachment. Including an open survey question on place meanings (such as in the Lahn study) may serve a similar purpose. The other case studies employed a quantitative approach limiting the possibilities for eliciting bottom-up information, but providing possibilities for measuring the strength of place attachment by use of psychometric scales (see ESM2).

The extent to which different forms or dimensions of sense of place were taken into account also differed between the research projects. This varied from essentially one variable (i.e. special places that foster a sense of attachment or identity; Caldes), a set of statements to measure different dimensions of place attachment (Waal and Skjern), to a combined range of questions and statements to elicit information about place meanings and place attachment (Lahn and Wigger). Place identity and place dependence were included either as a two-dimensional scale (Skjern and Lahn) or as part of multi-dimensional scale, also including social bonding, nature bonding and narrative bonding (Waal). The latter dimension emerged as a separate attribute of attachment for local residents, reflecting their connection via storytelling and knowledge of the past (Verbrugge and van den Born 2018).

Finally, there was a notable difference in the units used to measure sense of place. The approach taken in the Waal and Wigger cases was to measure people's attachment to (a part of) the river in general, or to the community or municipality. The Caldes, Lahn and Skjern studies, however, measured attachment to the specific locations people mapped.

\section{Relevant outcomes for river planning and management}

Here we report the relevant outcomes of the studies for river planning and management, including findings on attachment to and meanings of river sections and the potential of sense of place information to support participatory processes. Given the different forms of outputs of PPGIS studies compared to general surveys, we will group our findings according to the type of study.

\section{Attachment to and meanings of river landscapes}

PPGIS studies provided information about locations that people value, use often or that need improvement. In the study along the Skjern, 386 respondents mapped approximately 1000 places used for outdoor recreation. Places were mapped over a large area, hotspots being local woodlands, beaches, summerhouse areas and recreational harbours and the restored Skjern river valley (Figure S3 in ESM2). With about $25 \%$ of all mapped places, the river valley was the most popular single landscape element in the survey area among the respondents. This is remarkable considering that the river valley has only been accessible since the finalizing of the restoration project in 2002. A total of 780 mapped places included information on place dependence and place identity; however, there was no significant difference between these scores in the river valley compared to the other mapped hotspots (Table S4 in ESM2). But along the river, attachment scores were higher for sections of the river that were restored. Hence, the restored river valley constitutes an important collective sense of place hotspot adding to local peoples' identities and dependences, which supports a wide range of outdoor activities and outdoor recreation motives.

Results from the Lahn study (based on 1022 meaningful places located by 480 respondents) showed that meaningful places cluster around urban areas, rural areas, recreation areas as well as natural areas. The density of meaningful places was higher at rivers and lakes and in urban (green) areas when compared to agricultural areas and forests (Table S3 in ESM2). The frequency of meaningful places decreased with increasing distance from the river and its lakes (Gottwald and Albert 2018). The most often cited reason to mark a place as meaningful was that it enabled people to do a certain type of activity, such as biking, walking and canoeing. Other frequently mentioned reasons fall into the 'relational' category of Stephenson (2008) classifications (as opposed to 'forms' and 'practices'). Amongst these relationship-related meanings, aesthetics was mentioned most often, followed by well-being, friends and family, and memories. Mean scores for agreement with items within the place identity and place dependence dimensions showed that both are important but place identity had higher levels of agreement (3.75) than place dependence (3.50) (Table S2 in ESM2). For more than three-quarters of the mapped places (76.8\%) respondents reported a willingness to take action to preserve this place (Table S2 in ESM2). 
The Caldes study used positive and negative landscape values to better understand collective meanings embedded in specific places within this urban stream corridor. The most often mapped positive landscape values were recreational/ tourism $(n=269)$, cultural heritage $(n=267)$ and aesthetic/ scenic $(n=233)$. Special places (defined as places that foster a sense of attachment or identity) were mapped 130 times by 49 participants and ranked fifth on the list of 14 positive landscape values (Table S1 and Figure S1 in ESM2). A factor analysis including both negative and positive landscape values grouped the 'special places' item together with other positive landscape values, representing sites that are not only appreciated for their scenic beauty, cultural heritage and tourism opportunities, but also are regarded as having a high ecological, natural and ecosystem regulating value (Garcia et al. 2017). These combined 'attachment and amenity sites' often corresponded to agroforestry areas and urban river parks. Agroforestry areas are common in this stream corridor, but not all of them conveyed the same values. Urban river parks are highly valued settings but few in numbers.

The Wigger case study compared place meanings and place attachment scores between different river sections. It found that residents of all river sections were attached, irrespective of the ecological state of the river section. Residents of the municipality of Brittnau (one of the two sections where restoration has already taken place), reported slightly higher place attachment scores, in particular for the behavioural item (i.e. visiting frequency) (Table S6 in ESM2). In terms of place meanings, all sections were associated with a multitude of meanings. For two meanings significant variations could be determined, i.e. 'economic uses' and 'my life space'. The latter received higher scores for both restored river sections (Table S6 in ESM2). Respondents also reported to visit the restored sections more often, which was confirmed with the PPGIS findings (the preferred routes and in particular the favourite places) (Müller et al. 2017), while other popular places emerged along channeled river sections with historical industrial buildings. The large majority of residents along the Wigger supported restored scenarios and considered the status quo scenarios as deficient (Müller et al. 2017). Residents furthermore consistently perceived positive effects of the already realized restorations of the Wigger in terms of social benefits; however, the scores for perceived benefits decreased with increasing distance of the restored section to the respondents' place of residence, indicating a limited spatial reach (Table S6 in ESM2).

The Waal case study also found intermediate to strong attachment of residents and recreationists to the river, in particular in terms of place identity and nature bonding (Table S5 in ESM2). This study also investigated the role of place attachment in public support for a planned river intervention. These findings indicated that such relationships may differ between user groups. For water-based recreationists, place identity and dependence were negatively correlated with expected benefits of the dam (especially for recreational opportunities), signaling a resistance to change (Ganzevoort and van den Born 2018). For local residents, social bonding positively correlated with support for the intervention, possibly because of a dominant framing of the intervention as a protective flood risk measure (Verbrugge and van den Born 2018).

\section{Using outputs for facilitating participatory processes}

Mapping sense of place using a PPGIS approach made it possible to produce detailed spatial maps, which act as a useful tool for communicating the results in a multi-actor setting. Visual outputs of the Caldes study included maps with landscape values and improvement preferences, as well as maps showing potential conflicting values. These maps supported the development of a participatory process called "Viu la riera" (Live the stream) in which citizens, local organisations, experts and public authorities committed to the rehabilitation of the stream landscapes participated and shared opinions, knowledge, decisions and resources (www. viulariera.org). Meaningful places were introduced to Living Lahn actors during a participatory planning workshop. The concept of meaningful places was new to most of the participants; however, in general the information was evaluated as relevant and most participants stated interest in using it in their own work. For example, using a touch table with a map to show or assess meaningful places at stakeholder or local citizen meetings. Visual maps of the recreational use patterns have been used in local stakeholder discussions about land consolidation in parts of the Skjern river valley. Further analysis and map outputs will later be provided to the authorities in the river catchment area (municipalities and state) in order to support discussions with the general public about the future management (e.g. a possible designation of River Skjern as National Park).

Data gathered via 'traditional' surveys also provided relevant outcomes for participatory processes. Findings from the Waal study informed the design of a participatory monitoring project by identifying stakeholder groups who had high levels of concern in combination with high levels of attachment (Verbrugge et al. 2017). Moreover, data were shared in stakeholder meetings to support adaptive management and communication activities. One difficulty researchers experienced was to communicate the concept of place attachment to other stakeholders participating in the project, as it is difficult to grasp by non-experts. The quantitative approach, however, made it possible to compare between user groups (i.e. residents, recreational anglers and recreational boaters) which was useful to highlight their different needs. 
The combined approach using survey questions and mapping provided a solid informational basis for the Wigger restoration project. Residents' strong support for future river restoration projects legitimated the cantonal agencies to push forward a participatory planning of river restoration activities in the region and informed their communication strategy. The diversity in place meanings associated with the different river sections highlighted the importance of accounting for this heterogeneity in planning and designing the river sections, i.e. with reference to typical place characteristics (Müller et al. 2017). In this case, small-scale participatory events might be preferable to enable interested citizens to be involved in discussing, planning and/or implementing their restoration of 'their' part of the river.

\section{Discussion}

This study addressed two main questions: (1) how can sense of place be conceptualized and measured in river studies, and (2) how can the outcomes support participatory planning and management of river landscapes? Here, we discuss the benefits and challenges of different approaches and their potential contribution to resilient river management.

The motivations for studying sense of place were much in line with what Masterson et al. (2017b) listed as the assessment of ecosystem management, in particular for the assessment of preferences in planning or as an indicator of landscape values in general. Despite this common rationale, the conceptualizations of sense of place were quite diverse, ranging from special, meaningful and most visited places to attachment to the river itself. We illustrated that each approach has trade-offs and that they are in fact complementary. For example, a qualitative approach as employed in the Caldes study (see also Arias-Arévalo et al. 2017; Plieninger et al. 2018) is useful for eliciting place meanings and people's perceptions of change (see also Stedman 2016). Quantitative approaches measuring place attachment on psychometric scales provide a good reference for longitudinal or monitoring studies. Both approaches can be applied on different scales and with or without collecting spatially explicit information. One important recommendation for river managers is to be aware of, and combine, different approaches (depending on the context and main purposes) in order to yield relevant sense of place outcomes for assessing and monitoring rivers.

The Wigger and Skjern studies found higher attachment scores for sections of the river that were restored. The question arises as to whether people were already attached to the area or whether this is an effect of the intervention. There are several reasons to assert that these higher attachment scores can (at least) be partly attributed to river restoration. First, ecological restoration projects often depart from ecological and flood risk objectives, i.e. river sections are selected and restored independently of people's attitudes. This was also the case for the projects included in this study. Second, restored river sections, such as fluvial parks, often see an increase in visitors and public use of the area (e.g. Polizzi et al. 2015; and the Skjern and Wigger cases). New infrastructures, such as visitor facilities and cycle or walking paths, provide access and enable people to maintain or renew people place bonds, which may also explain why the frequency of meaningful places decreased with increasing distance from the Lahn river and its lakes. Finally, other place making activities, such as the communication and dissemination of the multiple benefits of large-scale restoration projects, are likely to contribute to higher visitation rates and sense of place.

Public involvement and adaptive learning among stakeholders are two important conditions for resilience-based management of social-ecological systems as they increase local knowledge use and the capacity to respond (Walker and Salt 2006). In line with Tadaki et al. (2017), we found that the assessment of sense of place is helpful to structure participation of different actors in decision-making. Our case studies illustrated the benefits of survey data and maps, either bottom-up through stimulating citizen initiatives or instigating public discussion on tangible issues, or top down to guide practitioners in involving citizens in planning and monitoring (see also Buchecker et al. 2010; Christensen and Burchfield 2013). A critical note, however, is that the study of sense of place in itself will not facilitate this dialogue between science, policy and society; it requires additional efforts to facilitate gatherings of citizens, researchers, planners and practitioners and enable joint knowledge co-creation processes.

\section{Limitations and recommendations for further research}

Case study research is restricted and the limitations of our study give rise to some further discussions. A first challenge relates to the low response rates for the surveys in residential areas (Table 1) and potential bias in samples, in particular when using online PPGIS. There are several (technical) issues that could prevent people from completing a PPGIS survey or to skip questions, for example because there is no convenient internet access or because (older) people have difficulty in understanding the survey or using a computer (Brown and Reed 2009; Gottwald et al. 2016). Potential hurdles that arose in our case studies 
included difficulties in using personal web links, difficulties in targeting specific audiences (e.g. visitors to a particular area) and surveys being too demanding when high numbers of pop-up questions appear for each mapped point. The Wigger case study had sufficient data to assess nonresponse bias by comparing the results from a long survey with a lower response rate with the results from a short survey with a higher response rate. The results showed that respondents of the longer questionnaire scored higher on sense of place items than respondents of the short questionnaire, indicating that less attached people were less willing to fill in the long questionnaire.

Second, none of the studies succeeds (yet) in explicitly examining the temporal dimension of sense of place. Often a lack of effort or resources for systematic assessments of sense of place and the absence of baseline data render it difficult to evaluate the social impact of river projects (but see Åberg and Tapsell 2013). In the Waal case, the period of 2 years between the surveys was experienced as too short and large differences in samples sizes in 2014 and 2016 further limited opportunities for comparison (Table 1). The planned follow-up studies for the Skjern and Wigger cases may address this issue, as they allow for the assessment regarding change of place use, attraction or initiation to stay at a place. In addition to longitudinal research design, future studies may also adjust their methodological approaches, for example by mapping places that people miss or consider as destroyed or by rephrasing survey items to capture the past and future (Di Masso et al. 2019). Other fruitful avenues to explore within our case studies is whether newcomers select different favorite places than long-term residents and whether supporters and opponents of planned restoration projects have different place preferences. New methods are being developed and combined to measure social place values, such as GPS tracking and linguistic approaches (Gosal et al. 2018; Wartmann and Purves 2018) as well as social media volunteered geographic information (e.g. analyses of shared images and tags from social media activities) (Jenkins et al. 2016; Guerrero et al. 2016). Such applications, in spite of their specific methodological limitations (e.g. high self-selection bias), may provide additional insights into the complementarity of different methods as well as their ability to elicit sense of place.

Finally, the comparative approach in this study was biased towards a researcher's perspective, excluding experiences from participants or practitioners. This may have been especially relevant in determining the motivations and drivers for doing this type of research. Further research is needed to elicit those other perspectives as well as to shed light on the different roles a researcher can take in monitoring and spurring practitioners into action.

\section{Conclusions}

Resilience-based river management requires new indicators for assessing and monitoring rivers as social-ecological systems. This will require a shift in thinking, particularly for river managers who are not naturally concerned with concepts such as sense of place. Our case study comparison showed that sense of place is conceptualized and measured in diverse ways and can be linked to different evaluative frameworks, i.e. places of recreational value, meaningful places or in relation to different scenarios. The choice in concepts and methods thus depends strongly on the purpose of the study and needs to be consciously made. A qualitative approach investigating place meanings may provide a wealth of information for planning, whereas a quantitative approach may be optimal to provide a baseline for evaluating psycho-social effects of river interventions. While both approaches can support participatory processes, collecting spatially explicit information on sense of place has the additional benefit of creating maps for communicating the often intangible sense of place findings to practitioners, policy makers and a general audience. Remaining challenges include finding ways to measure and evaluate sense of place in changing river landscapes (i.e. to capture the time element) as well as pushing the boundaries of institutional settings to reach a greater mutual understanding of the concept and its importance in river management and planning.

Acknowledgements The lead author is part of the research program RiverCare and is financed by NWO-TTW and the Ministry of Economic Affairs under grant number P12-14. The Caldes study received the support of RecerCaixa, a programme of Obra Social "la Caixa" in collaboration with the ACUP (2015ACUP 00184). The Skjern PPGIS survey was funded as part of the Danish Collective Impact initiative "The countryside as a double resource". The Wigger study was funded by the Department of Landscape and Water (Canton Aargau, Switzerland). The Lahn study was funded by the German Ministry for Education and Research (BMBF) through the Junior Research Group PlanSmart (01UU1601A) and received additional funding from the Graduate Academy of the Leibniz University Hannover.

Open Access This article is distributed under the terms of the Creative Commons Attribution 4.0 International License (http://creativeco mmons.org/licenses/by/4.0/), which permits unrestricted use, distribution, and reproduction in any medium, provided you give appropriate credit to the original author(s) and the source, provide a link to the Creative Commons license, and indicate if changes were made.

\section{References}

Åberg EU, Tapsell S (2013) Revisiting the River Skerne: the longterm social benefits of river rehabilitation. Landsc Urban Plan 113:94-103. https://doi.org/10.1016/j.landurbplan.2013.01.009

Adger WN, Barnett J, Chapin FS, Ellemor H (2011) This must be the place: underrepresentation of identity and meaning in climate change decision-making. Glob Environ Polit 11:1-25. https://doi. org/10.1162/GLEP_a_00051 
Agyeman J, Devine-Wright P, Prange J (2009) Close to the edge, down by the river? Joining up managed retreat and place attachment in a climate changed world. Environ Plan A 41:509-513. https://doi. org/10.1068/a41301

Altman I, Low SL (1992) Place attachment. Springer, Boston

Angelopoulos NV, Cowx IG, Buijse AD (2017) Integrated planning framework for successful river restoration projects: upscaling lessons learnt from European case studies. Environ Sci Policy 76:12-22. https://doi.org/10.1016/J.ENVSCI.2017.06.005

Arias-Arévalo P, Martín-López B, Gómez-Baggethun E (2017) Exploring intrinsic, instrumental, and relational values for sustainable management of social-ecological systems. Ecol Soc 22:art43. https://doi.org/10.5751/ES-09812-220443

Armstrong A, Stedman RC (2018) Understanding local environmental concern: the importance of place. Rural Sociol. https://doi. org/10.1111/ruso.12215

Begg C (2018) Power, responsibility and justice: a review of local stakeholder participation in European flood risk management. Local Environ 23:383-397. https://doi.org/10.1080/13549 839.2017.1422119

Benages-Albert M, Di Masso A, Porcel S et al (2015) Revisiting the appropriation of space in metropolitan river corridors. J EnvironPsychol 42:1-15. https://doi.org/10.1016/J.JENVP .2015.01.002

Brandenburg AM, Carroll MS (1995) Your place or mine? The effect of place creation on environmental values and landscape meanings. Soc Nat Resour 8:381-398. https://doi.org/10.1080/08941 929509380931

Brehm JM, Eisenhauer BW, Stedman RC (2013) Environmental concern: examining the role of place meaning and place attachment. Soc Nat Resour 26:522-538. https://doi.org/10.1080/08941 920.2012 .715726

Brown G, Reed P (2009) Public Participation GIS: a new method for use in national forest planning. Forest Sci 55:166-182. https://doi. org/10.1093/forestscience/55.2.166

Brunckhorst DJ (2000) Bioregional planning. Harwood Academic Publ, Australia

Buchecker M, Meier C, Hunziker M (2010) Measuring the effect of consensus building processes with methods of intervention research. Regional Planning Studies 18:259-280

Buijs AE (2009) Public support for river restoration. A mixed method study into local residents' support for and framing of river management and ecological restoration in the Dutch floodplains. $\mathbf{J}$ Environ Manag 90:2680-2689. https://doi.org/10.1016/j.jenvm an.2009.02.006

Burley D, Jenkins P, Laska S, Davis T (2007) Place attachment and environmental change in coastal Louisiana. Organ Environ 20:347-366. https://doi.org/10.1177/1086026607305739

Cantrill JG, Senecah SL (2001) Using the 'sense of self-in-place' construct in the context of environmental policy-making and landscape planning. Environ Sci Policy 4:185-203. https://doi. org/10.1016/S1462-9011(01)00023-5

Carpenter S, Walker B, Anderies JM, Abel N (2001) From metaphor to measurement: resilience of what to what? Ecosyst 4:765-781. https://doi.org/10.1007/s10021-001-0045-9

Chan KMA, Guerry AD, Balvanera P et al (2012) Where are cultural and social in ecosystem services? A framework for constructive engagement. Bioscience 62:744-756. https://doi.org/10.1525/ bio.2012.62.8.7

Christensen N, Burchfield J (2013) Place attachment for wildland recreation planning. In: Stewart WP, Williams DR, Kruger LE (eds) Place-Based Conservation. Springer, Dordrecht, pp 223-233

Davenport MA, Anderson DH (2005) Getting from sense of place to place-based management: an interpretive investigation of place meanings and perceptions of landscape change. Soc Nat Resour 18:625-641. https://doi.org/10.1080/08941920590959613
Di Masso A, Dixon J, Hernández B (2017) Place attachment, sense of belonging and the micro-politics of place satisfaction. In: FleuryBahi G, Pol E, Navarro O (eds) Handbook of environmental psychology and quality of life research. Springer, Cham, pp 85-104

Di Masso A, Williams DR, Raymond CM et al (2019) Between fixities and flows: navigating place attachments in an increasingly mobile world. J Environ Psychol 61:125-133. https://doi.org/10.1016/j. jenvp.2019.01.006

Dunham JB, Angermeier PL, Crausbay SD et al (2018) Rivers are social-ecological systems: time to integrate human dimensions into riverscape ecology and management. Wiley Interdiscip Rev Water 5:e1291. https://doi.org/10.1002/wat2.1291

Everard M, Moggridge HL (2012) Rediscovering the value of urban rivers. Urban Ecosyst 15:293-314. https://doi.org/10.1007/s1125 2-011-0174-7

Fliervoet JM, Geerling GW, Mostert E, Smits AJM (2015) Analyzing collaborative governance through social network analysis: a case study of river management along the Waal river in The Netherlands. Environ Manag 57:355-367. https://doi. org/10.1007/s00267-015-0606-x

Floress K, Akamani K, Halvorsen KE et al (2015) The role of social science in successfully implementing watershed management strategies. J Contemp Water Res Educ 154:85-105. https://doi. org/10.1111/j.1936-704X.2015.03189.X

Ganzevoort W, van den Born RJG (2018) Exploring place attachment and visions of nature of water-based recreationists: the case of the longitudinal dams. Landsc Res. https://doi. org/10.1080/01426397.2017.1415316

Garcia X, Benages-Albert M, Pavón D et al (2017) Public participation GIS for assessing landscape values and improvement preferences in urban stream corridors. Appl Geogr 87:184-196. https://doi.org/10.1016/J.APGEOG.2017.08.009

Gosal AS, Newton AC, Gillingham PK (2018) Comparison of methods for a landscape-scale assessment of the cultural ecosystem services associated with different habitats. Int J Biodivers Sci Ecosyst Serv Manag 14:91-104.https://doi.org/10.1080/21513 732.2018 .1447016

Gottwald S, Albert C (2018) Assessing sense of place to support river landscape planning. In: Huismans Y, Berends KD, Niesten I, Mosselman E (eds) The future river-NCR DAYS 2018 proceedings. NCR-publication 42-2018, pp 60-61

Gottwald S, Laatikainen TE, Kyttä M (2016) Exploring the usability of PPGIS among older adults: challenges and opportunities. Int J Geogr Inf Sci 30:2321-2338. https://doi.org/10.1080/13658 816.2016.1170837

Guerrero P, Møller MS, Olafsson AS, Snizek B (2016) Revealing cultural ecosystem services through Instagram images: the potential of social media volunteered geographic information for urban green infrastructure planning and governance. Urban Plan 1:1-17. https://doi.org/10.17645/up.v1i2.609

Hausmann A, Slotow R, Burns JK, Di Minin E (2016) The ecosystem service of sense of place: benefits for human well-being and biodiversity conservation. Environ Conserv 43:117-127. https ://doi.org/10.1017/S0376892915000314

Henze J, Schröter B, Albert C (2018) Knowing me, knowing you Capturing different knowledge systems for river landscape planning and governance. Water 10:934. https://doi.org/10.3390/ w10070934

Hillman M (2009) Integrating knowledge: the key challenge for a new paradigm in river management. Geogr Compass 3:19882010. https://doi.org/10.1111/j.1749-8198.2009.00278.x

Ingalls M, Stedman R (2017) Engaging with human identity in social-ecological systems: a dialectical approach. Human Ecology Review 23:45-64 
Ives CD, Kendal D (2014) The role of social values in the management of ecological systems. J Environ Manag 144:67-72. https ://doi.org/10.1016/J.JENVMAN.2014.05.013

Jenkins A, Croitoru A, Crooks AT, Stefanidis A (2016) Crowdsourcing a collective sense of place. PLoS ONE 11(4):e0152932. https://doi.org/10.1371/journal.pone.0152932

Junker B, Buchecker M, Müller-Böker U (2007) Objectives of public participation: which actors should be involved in the decision making for river restorations? Water Resour Res 43:W10438. https://doi.org/10.1029/2006wr005584

Junot A, Paquet Y, Fenouillet F (2018) Place attachment influence on human well-being and general pro-environmental behaviors. J Theor Soc Psychol 2:49-57. https://doi.org/10.1002/jts5.18

Kianicka S, Buchecker M, Hunziker M, Müller-Böker U (2006) Locals' and tourists' sense of place. Mt Res Dev 26:55-63. https://doi.org/10.1659/0276-4741

Kyle G, Graefe A, Manning R (2005) Testing the dimensionality of place attachment in recreational settings. Environ Behav 37:153-177. https://doi.org/10.1177/0013916504269654

Masterson V, Tengö M, Spierenburg M (2017a) Competing place meanings in complex landscapes: a social-ecological approach to unpacking community conservation outcomes on the Wild Coast, South Africa. Soc Nat Resour 30:1442-1457. https://doi. org/10.1080/08941920.2017.1347975

Masterson VA, Stedman RC, Enqvist J et al (2017b) The contribution of sense of place to social-ecological systems research: a review and research agenda. Ecol Soc 22:art49. https://doi.org/10.5751/ ES-08872-220149

Menzel S, Buchecker M (2013) Does participatory planning foster the transformation toward more adaptive socio-ecological systems? Ecol Soc 18:1-13. https://doi.org/10.5751/ES-05154-180113

Müller S, Buchecker M, Gaus R et al (2017) Wie soll die Wigger in der Region Zofingen in Zukunft gestaltet werden? Wasser Energie Luft 109(3):181-189

Nicolosi E, Corbett JB (2018) Engagement with climate change and the environment: a review of the role of relationships to place. Local Environ 23:77-99. https://doi.org/10.1080/13549839.2017.13850 02

Pahl-Wostl C (2015) Water governance in the face of global change: From understanding to transformation. Springer, Cham

Parsons M, Thoms MC, Flotemersch J, Reid M (2016) Monitoring the resilience of rivers as social-ecological systems: a paradigm shift for river assessment in the twenty-first century. In: Gilvear DA, Greenwood MW, Thoms MC, Wood PA (eds) River science: research and management for the 21st century. Wiley-Blackwell, Chichester, pp 197-220

Plieninger T, Rana HÁA, Fagerholm N et al (2018) Identifying and assessing the potential for conflict between landscape values and development preferences on the Faroe Islands. Glob Environ Change 52:162-180. https://doi.org/10.1016/j.gloen vcha.2018.07.006

Polizzi C, Simonetto M, Barausse A et al (2015) Is ecosystem restoration worth the effort? The rehabilitation of a Finnish river affects recreational ecosystem services. Ecosystem Services 14:158-169. https://doi.org/10.1016/j.ecoser.2015.01.001

Proshansky HM, Fabian AK, Kaminoff R (1983) Place-identity: physical world socialization of the self. J Environ Psychol 3:57-83. https://doi.org/10.1016/S0272-4944(83)80021-8

Quinn T, Bousquet F, Guerbois C et al (2018) The dynamic relationship between sense of place and risk perception in landscapes of mobility. Ecol Soc. https://doi.org/10.5751/ES-10004-230239

Rojas R, Feyen L, Watkiss P (2013) Climate change and river floods in the European Union: socio-economic consequences and the costs and benefits of adaptation. Glob Environ Change 23:1737-1751. https://doi.org/10.1016/J.GLOENVCHA.2013.08.006
Schönach P (2017) River histories: a thematic review. Water Hist 9:233-257. https://doi.org/10.1007/s12685-016-0188-4

Sendzimir J, Magnuszewski P, Gunderson L (2018) Adaptive management of riverine socio-ecological systems. In: Schmutz S, Sendzimir J (eds) Riverine ecosystem management: Science for governing towards a sustainable future. Springer International Publishing, Cham, pp 301-324

Simoni J, Floress K (2015) An exploration of place meanings among residents in central Wisconsin. Lake Reserv Manag 31:1-10. https ://doi.org/10.1080/10402381.2014.963755

Stedman RC (2002) Toward a social psychology of place: predicting behavior from place-based cognitions, attitude, and identity. Environ Behav 34:561-581. https://doi.org/10.1177/0013916502 034005001

Stedman RC (2003) Is it really just a social construction? The contribution of the physical environment to sense of place. Soc Nat Res 16:671-685. https://doi.org/10.1080/08941920309189

Stedman RC (2016) Subjectivity and social-ecological systems: a rigidity trap (and sense of place as a way out). Sustain Sci 11:891-901. https://doi.org/10.1007/s11625-016-0388-y

Stephenson J (2008) The cultural values model: an integrated approach to values in landscapes. Landsc Urban Plan 84:127-139. https:// doi.org/10.1016/j.landurbplan.2007.07.003

Straatsma MW, Bloecker AM, Lenders HJR et al (2017) Biodiversity recovery following delta-wide measures for flood risk reduction. Sci Adv 3:e1602762.https://doi.org/10.1126/sciadv.1602762

Tadaki M, Sinner J, Chan KMA (2017) Making sense of environmental values: a typology of concepts. Ecol Soc. https://doi.org/10.5751/ ES-08999-220107

Tuan YF (1977) Space and place: the perspective of experience. University of Minnesota Press, Minneapolis

Verbrugge LNH, van den Born RJG (2018) The role of place attachment in public perceptions of a re-landscaping intervention in the river Waal (The Netherlands). Landsc Urban Plan 177:241-250. https://doi.org/10.1016/J.LANDURBPLAN.2018.05.011

Verbrugge LNH, Ganzevoort W, Fliervoet JM et al (2017) Implementing participatory monitoring in river management: the role of stakeholders' perspectives and incentives. J Environ Manag 195:62-69. https://doi.org/10.1016/j.jenvman.2016.11.035

Walker B, Salt D (2006) Resilience thinking: Sustaining ecosystems and people in a changing world. Island Press, Washington

Wartmann FM, Purves RS (2018) Investigating sense of place as a cultural ecosystem service in different landscapes through the lens of language. Landsc Urban Plan 175:169-183. https://doi. org/10.1016/J.LANDURBPLAN.2018.03.021

Williams DR (2008) Pluralities of place: A user's guide to place concepts, theories, and philosophies in natural resource management. In: Kruger LE, Hall TE, Stiefel MC (eds) Understanding concepts of place in recreation research and management. Gen. Tech. Rep. PNW-GTR-744, US Department of Agriculture, Portland (OR), pp 7-30

Williams DR, Vaske JJ (2003) The measurement of place attachment: validity and generalizability of a psychometric approach. For Sci 49:830-840

Yeakley AJ, Ervin D, Chang H et al (2016) Ecosystem services of streams and rivers. In: Gilvear D, Greenwood M, Thoms M, Wood $P$ (eds) River science: research and management for the 21 st century. Wiley-Blackwell, Chichester, pp 335-352

Yin RK (1994) Case study research: design and methods. Sage, Newbury Park

Publisher's Note Springer Nature remains neutral with regard to jurisdictional claims in published maps and institutional affiliations. 